International Journal of Engineering \& Technology, $7(3.30)(2018) 188-193$
International Journal of Engineering \& Technology
Website: www.sciencepubco.com/index.php/IJET
Research paper

\title{
Literacy Virtual Entrepreneur in Indonesia
}

\author{
Arnold Tindas ${ }^{1,6}$, Suryadi Sumarlin ${ }^{2}$, Sasmoko $^{3,6^{*}}$, Jimmy B Oentoro $^{4}$, Yasinta Indrianti ${ }^{5,6}$ \\ ${ }^{1,2,4}$ Doctoral Program, Harvest International Theological Seminary, Jakarta, Indonesia \\ ${ }^{3}$ Primary Teacher Education Department, Faculty of Humanities, Bina Nusantara University, Jakarta, Indonesia \\ ${ }^{5}$ Faculty of Social, Podomoro University, Jakarta, Indonesia \\ ${ }^{6}$ Research Interest Group in Educational Technology, Bina Nusantara University, Jakarta, Indonesia \\ *Corresponding authorE-mail: sasmoko@binus.edu
}

\begin{abstract}
The potential strength of entrepreneurship in Indonesia lies in the potential of human resources who are a literate internet. Nevertheless, there are still some weaknesses that are not yet equal to the ability. The problem is how is the condition of Indonesian entrepreneur about its virtual literacy? Construct Validity uses the Item Response Theory (IRT) approach through Orthogonal Iteration. The reason, because all dimensions and indicators are the results of the theoretical studies are called as signs of the variables Literacy Virtual Entrepreneur Indonesia (Y). The number of samples of the instrument test was 81 entrepreneurs consisting of 27 districts/cities each represented 3 entrepreneurs. The R-criteria of the Product Moment is set at 0.221 . Of the 32 items planned, proved to be all valid. The reliability of "valid instrument" of the Virtual Literacy variables of Entrepreneur Indonesia (Y) as internal consistency is calculated by Cronbach Alpha formula, the result is 0.892 . Research methods with Neuroresearch. The result of the research: Firstly, Indonesian entrepreneurs tend to be significantly virtual literate on $\alpha<0,05$. Second, having the capacity to realize information technology literacy (X4) is the most powerful indicator to realize the formation of Literacy Virtual Entrepreneur Indonesia (Y). It is able to determine an increase of 83,521 times from the condition of Literacy Virtual Entrepreneur Indonesia (Y).
\end{abstract}

Keywords: Literacy Virtual Entrepreneur, Neuroresearch.

\section{Introduction}

Entrepreneurship is not a science or an art, but a practice or means used to achieve entrepreneurial goals and practices are important for the advancement of a nation because it is considered as an economic engine $[1,2,3]$. Although initially entrepreneurship more related to small and medium enterprises [4]. In Indonesia, entrepreneurship is developing well and become an important factor in economic development [5]. The first position in the 2017 Global Entrepreneurship Monitor was won by the United States. While neighboring countries namely Singapore reached the 24th position, Malaysia 54th, Thailand to-65 and Philippines 76th. This means that the position of competitiveness of Indonesian entrepreneurship and creativity at the global level is still relatively lagging behind other countries, especially in ASEAN [6].

With the development of digital lifestyles where the internet has reached $51.8 \%$ of the population in Indonesia, Indonesia is increasingly having great potential to develop entrepreneurship because the growth of the internet has proven to be able to trigger the development of start-up [6]. This potential is strongly supported by the government with the drafting of a National Law on Entrepreneurship in which one of the considerations states that national entrepreneurship is an effort to create ways of working combined with efficient use of technology that aims to obtain greater profits [7]

Entrepreneurship has 14 pillars mentioned in the Global entrepreneurship and development index (GEDI). To be optimal these pillars need to be considered consistently, continuous improvement and careful care because they must remain balanced $[8,9]$.
Of the fourteen pillars, the absorption of technology has become an interesting subject. The development of the 21 st century has made technology a distinctive feature because of its rapid development. With the use of technology as one of the pillars, then as a 21 st-century entrepreneur must also be able to absorb and apply technology in running its business. The emphasis is on knowledge, services, and information that creates opportunities for new companies to emerge. In addition, the development of this century makes the old companies began to hire employees who have skills with a higher level in order to be competitive [10]. 21st-century skills related to entrepreneur skills can be seen from the following picture:

From the picture above it is stated that one of the important things is technology literacy. Information literacy, media and technology categories in the 21st Century Knowledge, Skills, and Abilities (21st century KSA) refer to the ability to think and reason logically to solve complex problems actively and full of initiative. Information literacy is the hallmark of the 21 st century as it relates to the ability to generate meaning and knowledge from the information obtained [10].

In comparison, in Malaysia entrepreneurs who are quite dependable are agro-based entrepreneurs. The Malaysian government is very supportive because they can strengthen the country's economy. Government support is realized through development efforts in the agricultural sector which are expected not only to rely on traditional methods. With the advent of technology, the Malaysian government hopes that this argo-based entrepreneur can emulate farmers in Japan, Taiwan and Australia as role models of modern agro-based entrepreneurs because they have applied modern technology and made it a new culture in running their business. However, the major obstacles facing the Malaysian government are the 


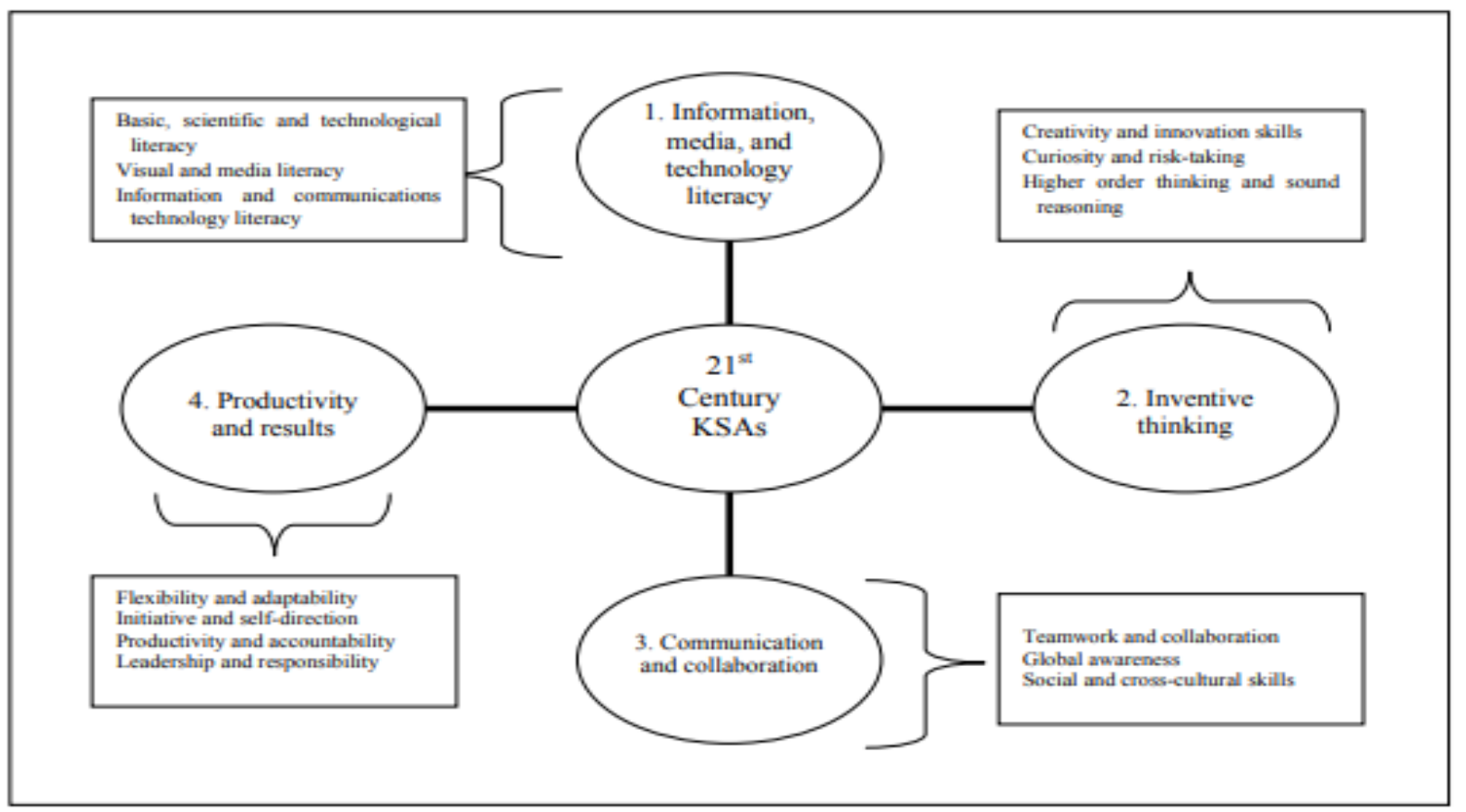

Picture 1: 21th Century Knowledge, Skills and Abilities [10]

problems and benefits in the use of information and communication technology.

The results concluded that there are five main problems faced are: 1) agro-based entrepreneurs do not know the benefits of using information and communication technology; 2) agro-based entrepreneurs do not have skills in using information and communication technology; 3) lack of time for agro-based entrepreneurs that can be used to hone information and communication technology skills and 4) lack of agro-based entrepreneur knowledge on information and communication technology [11].

Information literacy, especially about technology, is being promoted in the field of education because it provides students with opportunities to explore how information and knowledge shape their lives, their communities, and the world. By studying information literacy they can become critical information users, learning how to place information and knowledge in a wider and diverse environment. One of the goals of learning information literacy is to make technology a foundation to provide opportunities to utilize rich and interactive technological capabilities, ask questions, identify problems and find solutions to these problems, progress at their own pace and gain access to the necessary learning resources. which emphasizes togetherness and thought patterns critically and creatively, acting as mentors who help others face problems and challenges and are responsible for the learning they experience and try to reach their highest expectations. this practice is very appropriate when implemented in the world of entrepreneurs [12].

By looking at technological progress and most of the population in Indonesia has implemented millennial patterns, literacy studies are not only enough to stop the exploration of virtual entrepreneurial literacy. But it will be more appropriate when realized through an application that can be accessed anywhere and anytime. This is important because entrepreneurs are now considered as an aggressive catalyst for changes in the business world because they are able to see opportunities that are not seen by others [13].

The rapid growth of information technology has recently influenced the way humans collect, process and share information. This growth is supported by the application of the Internet in almost all human activities. The effectiveness of Internet users is dominated by 82.2 million (62\%) workers/entrepreneurs of 132.7 million Internet users in Indonesia in 2016. The use of the Internet is accessed more than smartphone devices as much as 89.9 million $(67.8 \%)$ as shown in the picture below [14].

By looking at the development of technology and the use of the internet at this time, this research seeks to build an Indonesian Virtual Entrepreneurial Literacy Index through an Intelligent System Based on Android Applications.

\section{Literature Review}

\subsection{Entrepreneurship}

Entrepreneurship is multifaceted which can be understood from various perspectives [15]. Entrepreneurship plays an important role especially in modern urban growth because it is a driving force for current economic development $[16,17]$. The Global Entrepreneurship and Development Index (GEDI) presents three sub-indices namely attitudes towards entrepreneurship, the ability of entrepreneurship and entrepreneurial aspirations [8,9].

There are 14 pillars mentioned in the Global Entrepreneurship and development index (GEDI) which are included in three subindexes. Entrepreneurial attitude consists of 1) perception of opportunity; 2) start up skills; 3 ) the ability to accept risks; 4) networking; and 5) cultural support. Entrepreneurial attitude is the attitude of society towards entrepreneurship which is based on the survey results about the general feeling of the population in recognizing opportunities, getting to know entrepreneurs personally, giving awards to entrepreneurs with high status, accepting risks when starting a business and having the skills to launch a business successfully. The population is also considered capable of providing potential cultural, financial and networking support for entrepreneurs. Countries need people who can recognize valuable business opportunities, and who believe they have the skills needed to take advantage of this opportunity. Especially if the nation's attitude towards entrepreneurship is positive, it will result in cultural support, financial support, and network benefits for those who want to start a business $[8,9]$.

Entrepreneurial ability is supported by several pillars, including 6) opportunities to develop start-ups; 7) absorption of technology; 8) human capital, and 9) competitiveness. Entrepreneurial ability refers to the characteristics of entrepreneurs in business. The diversity of business fields, entrepreneur demography becomes 
one of the factors that determine the development of entrepreneurship. Success in this regard is also supported by motivational opportunities as a sign of good planning, sophisticated strategies and high growth in the start-up developed $[8,9]$.

While entrepreneurial aspirations are supported by pillars of 10) product innovation; 11) innovation development process; 12) growth rate; 13) internationalization and 14) capital risk. The entrepreneurial aspiration reflects the quality aspect of the startup or a newly developed business. Some people don't like their boss and want to develop their own business. Entrepreneurial aspiration is defined as the effort of entrepreneurs in the early stages to introduce new products or services, develop new production processes, penetrate foreign markets, increase the number of employees and finance their business with business capital both obtained formally and informally. Product innovation, the process of innovation and internationalization and high growth become the main characteristics of entrepreneurial $[8,9]$.

\subsection{Kompetensi Entrepreneurial}

Boyle [10] summarizes the entrepreneurial competency framework and 21th Century Knowledge, Skills and Abilities with the following explanation:

The first entrepreneurial competence is related to the cognitive aspects of the discernment of opportunity, entrepreneurial awareness theory, the ability to seek information systematically and creatively. This competency consists of two things, namely Ability in terms of information, media and technology literacy. this ability is related to the ability to reason logically to solve complex problems, the ability to generate meaning and knowledge of information, the ability to evaluate information critically and filter it become more relevant in accordance with its usefulness and the ability to recognize patterns and develop divergent thinking.

The ability to think inventively, ie the ability to accompany action to bring something new and original or in other words able to apply through analysis, comparison, concluding and interpretation and synthesis to develop new solutions to complex problems.

The second entrepreneurial competency is related to social competency that involves entrepreneurship which is considered a social process, human and social skills, social capital and access to resources. This competence deals with communication skills and interaction collaboration together to solve problems and create an innovation, the ability to read and manage the emotions of self and others, as well as the ability to communicate and create meaning through the various tools used and the process through which it passes.

The third entrepreneurial competence is oriented towards action initiatives involving self-efficacy or individual ability to perform tasks, self-management capabilities related to planning and evaluation processes, ability to stay proactive and focus on controlling outcomes and personal responsibility to achieve the best results. This competence relates to productivity and outcomes: the ability to utilize time and resources efficiently and effectively, to develop plans and monitor progress effectively as a form of implementation of the plan, self-evaluation, flexibility, adaptability, initiative and self-direction and accountability. owned.

\section{Research Method}

This study uses the neuroresearch method, which is a method that collaborates quantitative and qualitative research in every stage that is carried out so as to obtain a comprehensive study and analysis $[18,19]$. The first stage is a qualitative method. At this stage, the researcher carried out a review literature so as to obtain a theoretical study as well as constructing a construct to produce an appropriate research instrument [20]. This stage is then continued with quantitative methods with data retrieval and analysis in the neuroresearch method called the explanatory stage and confirmatory research [21].

\section{Results}

Each region of Indonesia (western, central and eastern Indonesia) is represented by 180 entrepreneurs (33.3\%) respectively. In detail can be seen in the following table.

\begin{tabular}{|rl|r|r|r|r|}
\multicolumn{7}{|c|}{ INDO_TERITORY } \\
\hline & & Frequency & Percent & Valid Percent & $\begin{array}{c}\text { Cumulative } \\
\text { Percent }\end{array}$ \\
\hline Valid & West & 180 & 33.3 & 33.3 & 33.3 \\
& Central & 180 & 33.3 & 33.3 & 66.7 \\
& East & 180 & 33.3 & 33.3 & 100.0 \\
& Total & 540 & 100.0 & 100.0 & \\
\hline
\end{tabular}

Each region of Indonesia (western, central and eastern Indonesia) is represented by 3 (three) provinces, namely the Western Indonesia Region represented by DKI Jakarta, West Java, and Lampung. The central part of Indonesia is represented by North Sulawesi, South Sulawesi, and East Sulawesi. And eastern Indonesia is represented by the provinces of Papua, West Papua, and North Malu$\mathrm{ku}$. Each is represented by 60 entrepreneurs $(11.1 \%)$. In detail can be seen in the following table.

\begin{tabular}{|c|c|c|c|c|c|}
\hline \multicolumn{6}{|c|}{ PROVINCE } \\
\hline & & Frequency & Percent & Valid Percent & $\begin{array}{c}\text { Cumulative } \\
\text { Percent }\end{array}$ \\
\hline \multirow[t]{10}{*}{ Valid } & DKI & 60 & 11.1 & 11.1 & 11.1 \\
\hline & West Java & 60 & 11.1 & 11.1 & 22.2 \\
\hline & Lampung & 60 & 11.1 & 11.1 & 33.3 \\
\hline & North Sulawesi & 60 & 11.1 & 11.1 & 44.4 \\
\hline & South Sulawesi & 60 & 11.1 & 11.1 & 55.6 \\
\hline & East Kalimantan & 60 & 11.1 & 11.1 & 66.7 \\
\hline & Papua & 60 & 11.1 & 11.1 & 77.8 \\
\hline & West Papua & 60 & 11.1 & 11.1 & 88.9 \\
\hline & North Maluku & 60 & 11.1 & 11.1 & 100.0 \\
\hline & Total & 540 & 100.0 & 100.0 & \\
\hline
\end{tabular}

Each cluster member province is represented randomly by 3 regencies/cities with each represented by 20 entrepreneurs in the area $(3.7 \%)$. In detail can be seen in the following table.

\begin{tabular}{|c|c|c|c|c|c|}
\hline \multicolumn{6}{|c|}{ DISTRICT } \\
\hline & & Frequency & Percent & Valid Percent & $\begin{array}{l}\text { Cumulative } \\
\text { Percent }\end{array}$ \\
\hline \multirow[t]{28}{*}{$\begin{array}{l}\text { Valid } \\
\end{array}$} & West Jakarta & 20 & 3.7 & 3.7 & 3.7 \\
\hline & North Jakarta & 20 & 3.7 & 3.7 & 7.4 \\
\hline & East Jakarta & 20 & 3.7 & 3.7 & 11.1 \\
\hline & Bogor & 20 & 3.7 & 3.7 & 14.8 \\
\hline & Sukabumi & 20 & 3.7 & 3.7 & 18.5 \\
\hline & Tasikmalaya & 20 & 3.7 & 3.7 & 22.2 \\
\hline & Kota Metro & 20 & 3.7 & 3.7 & 25.9 \\
\hline & Kota Bandar Lampung & 20 & 3.7 & 3.7 & 29.6 \\
\hline & Mesuji & 20 & 3.7 & 3.7 & 33.3 \\
\hline & Bitung & 20 & 3.7 & 3.7 & 37.0 \\
\hline & Minahasa Utara & 20 & 3.7 & 3.7 & 40.7 \\
\hline & Kota Manado & 20 & 3.7 & 3.7 & 44.4 \\
\hline & Kota Makassar & 20 & 3.7 & 3.7 & 48.1 \\
\hline & Toraja Utara & 20 & 3.7 & 3.7 & 51.9 \\
\hline & Gowa & 20 & 3.7 & 3.7 & 55.6 \\
\hline & Kota Balikpapan & 20 & 3.7 & 3.7 & 59.3 \\
\hline & Kutai Kartanegara & 20 & 3.7 & 3.7 & 63.0 \\
\hline & Kutai Barat & 20 & 3.7 & 3.7 & 66.7 \\
\hline & Merauke & 20 & 3.7 & 3.7 & 70.4 \\
\hline & Kota Jayapura & 20 & 3.7 & 3.7 & 74.1 \\
\hline & Asmat & 20 & 3.7 & 3.7 & 77.8 \\
\hline & Sorong & 20 & 3.7 & 3.7 & 81.5 \\
\hline & Manokwari & 20 & 3.7 & 3.7 & 85.2 \\
\hline & Teluk Bintuni & 20 & 3.7 & 3.7 & 88.9 \\
\hline & Kota Ternate & 20 & 3.7 & 3.7 & 92.6 \\
\hline & Halmahera Utara & 20 & 3.7 & 3.7 & 96.3 \\
\hline & Pulau Morotai & 20 & 3.7 & 3.7 & 100.0 \\
\hline & Total & 540 & 100.0 & 100.0 & \\
\hline
\end{tabular}

As many as 343 people $(63.5 \%)$ of respondent's male sex, while women as much as 197 respondents (36.5\%). Although the number of female entrepreneurs is fewer but has a proportion exceed- 
ing $50 \%$ of the number of male entrepreneurs. In detail can be seen in the following table.

\begin{tabular}{|c|c|c|c|c|c|}
\hline \multicolumn{6}{|c|}{ SEX } \\
\hline & & Frequency & Percent & Valid Percent & $\begin{array}{c}\text { Cumulative } \\
\text { Percent }\end{array}$ \\
\hline \multirow[t]{3}{*}{ Valid } & Male & 343 & 63.5 & 63.5 & 63.5 \\
\hline & Female & 197 & 36.5 & 36.5 & 100.0 \\
\hline & Total & 540 & 100.0 & 100.0 & \\
\hline
\end{tabular}

A total of 206 respondents $(38.1 \%)$ were $\leq 23$ years old. Respondents aged $24-38$ years were 117 people $(21.7 \%)$, aged $39-53$ years as many as 167 people (30.9\%). Senior entrepreneurs are aged 5472 years as many as 50 people $(9.3 \%)$. That is, randomly, the sample represents the age group as junior / young to adult / senior entrepreneurs. In detail can be seen in the following table.

\begin{tabular}{|c|c|c|c|c|c|}
\hline \multicolumn{6}{|c|}{ AGE } \\
\hline & & Frequency & Percent & Valid Percent & $\begin{array}{c}\text { Cumulative } \\
\text { Percent }\end{array}$ \\
\hline Valid & $<=23$ years & 206 & 38.1 & 38.1 & 38.1 \\
\hline & $24-38$ years & 117 & 21.7 & 21.7 & 59.8 \\
\hline & $39-53$ years & 167 & 30.9 & 30.9 & 90.7 \\
\hline & $54-72$ years & 50 & 9.3 & 9.3 & 100.0 \\
\hline & Total & 540 & 100.0 & 100.0 & \\
\hline
\end{tabular}

A total of 227 respondents (42\%) with a senior high school education background. And the least come from vocational schools as much as 1 person $(0.2 \%)$. In detail can be seen in the following table.

\begin{tabular}{|c|c|c|c|c|c|}
\hline \multicolumn{6}{|c|}{ EDUC_LEV } \\
\hline & & Frequency & Percent & Valid Percent & $\begin{array}{c}\text { Cumulative } \\
\text { Percent }\end{array}$ \\
\hline \multirow[t]{8}{*}{ Valid } & $\begin{array}{l}\text { Primary_School } \\
\text { Pry }\end{array}$ & $\begin{array}{r}74 \\
\end{array}$ & 13.7 & $\begin{array}{r}13.7 \\
\end{array}$ & 13.7 \\
\hline & Junior_high_school & 19 & 3.5 & 3.5 & 17.2 \\
\hline & Senior_High_School & 227 & 42.0 & 42.0 & 59.3 \\
\hline & Bachelor & 195 & 36.1 & 36.1 & 95.4 \\
\hline & Master & 22 & 4.1 & 4.1 & 99.4 \\
\hline & Doctor & 2 & .4 & .4 & 99.8 \\
\hline & Vocational & 1 & .2 & .2 & 100.0 \\
\hline & Total & 540 & 100.0 & 100.0 & \\
\hline
\end{tabular}

A total of 353 respondents (65.4\%) came from domestic education graduates. While the remaining 187 respondents (34.6\%) came from overseas education graduates. In detail can be seen in the following table.

\begin{tabular}{|c|c|c|c|c|c|}
\hline \multicolumn{6}{|c|}{ EDUC_LOC } \\
\hline & & Frequency & Percent & Valid Percent & $\begin{array}{c}\text { Cumulative } \\
\text { Percent }\end{array}$ \\
\hline \multirow[t]{3}{*}{ Valid } & Overseas & 187 & 34.6 & 34.6 & 34.6 \\
\hline & Domestic & 353 & 65.4 & 65.4 & 100.0 \\
\hline & Total & 540 & 100.0 & 100.0 & \\
\hline
\end{tabular}

A total of 387 respondents (71.7\%) managed their business in full time. While the rest is managed partially (part time) as many as 153 respondents $(28.3 \%)$. In detail can be seen in the following table.

\begin{tabular}{|ll|r|r|r|r|}
\multicolumn{7}{|c|}{ B_MANAGE } \\
\hline & & Frequency & Percent & Valid Percent & $\begin{array}{c}\text { Cumulative } \\
\text { Percent }\end{array}$ \\
\hline Valid & Full Time & 387 & 71.7 & 71.7 & 71.7 \\
& Part Time & 153 & 28.3 & 28.3 & 100.0 \\
& Total & 540 & 100.0 & 100.0 & \\
\hline
\end{tabular}

A total of 305 respondents (56.5\%) of businesses developed status have been running regularly. However, other facts show that 121 respondents $(22.4 \%)$ of their business are routine but at the time this research is in the stage of developing new business. In detail can be seen in the following table.

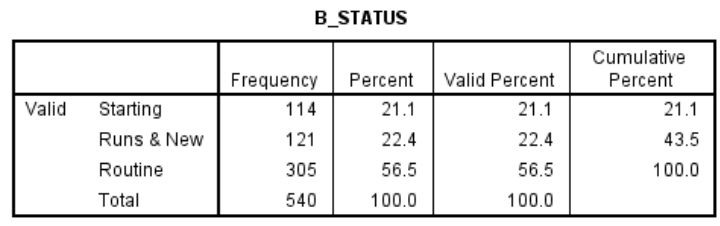

A total of 490 respondents $(90.7 \%)$ developed businesses managed by the owner themselves. The remaining $9.3 \%$ is staffed. In detail can be seen in the following table.

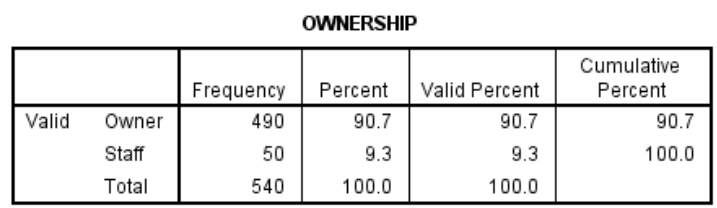

A total of 273 respondents (50.6\%) have experience to be entrepreneurs $<5$ years. Followed by $11-20$ years as many as 137 respondents $(25.4 \%)$. The fewest of the senior group as entrepreneurs and have experience> 20 years as many as 38 respondents (7\%). In detail can be seen in the following table.

\begin{tabular}{|c|c|c|c|c|c|}
\hline \multicolumn{6}{|c|}{ EXPERIENCE } \\
\hline & & Frequency & Percent & Valid Percent & $\begin{array}{c}\text { Cumulative } \\
\text { Percent }\end{array}$ \\
\hline \multirow[t]{5}{*}{ Valid } & $<5$ years & 273 & 50.6 & 50.6 & 50.6 \\
\hline & $5-10$ years & 92 & 17.0 & 17.0 & 67.6 \\
\hline & $11-20$ years & 137 & 25.4 & 25.4 & 93.0 \\
\hline & $>20$ years & 38 & 7.0 & 7.0 & 100.0 \\
\hline & Total & 540 & 100.0 & 100.0 & \\
\hline
\end{tabular}

A total of 235 respondents $(43.5 \%)$ had a culinary business and the second most represented by respondents with a fashion business that was 103 respondents (19.1\%). In detail can be seen in the following table.

\begin{tabular}{|l|r|r|r|r|}
\hline \multicolumn{5}{|c|}{ B_TrPE } \\
\hline Valid Art & Frequency & Percent & Valid Percent & \multicolumn{1}{c|}{$\begin{array}{c}\text { Cumulative } \\
\text { Percent }\end{array}$} \\
\hline Performaing_Arts & 5 & .9 & .9 & .9 \\
TV \& Radio & 2 & .4 & .4 & 1.3 \\
Publishing & 4 & .7 & .7 & 2.0 \\
Apps_Game_Dev & 3 & .6 & .6 & 2.6 \\
Fashion & 5 & .9 & .9 & 3.5 \\
Music & 103 & 19.1 & 19.1 & 22.6 \\
Culinary & 4 & .7 & .7 & 23.3 \\
Craft & 235 & 43.5 & 43.5 & 66.9 \\
Photography & 4 & .7 & .7 & 67.6 \\
Product_Design & 3 & .6 & .6 & 68.1 \\
Visual_Comm_Design & 23 & 4.3 & 4.3 & 72.4 \\
Interior_Design & 2 & .4 & .4 & 72.8 \\
Electronics & 8 & 1.5 & 1.5 & 74.3 \\
Services & 3 & .6 & .6 & 74.8 \\
Contractor & 51 & 9.4 & 9.4 & 84.3 \\
Automotive & 27 & 5.0 & 5.0 & 89.3 \\
Online & 9 & 1.7 & 1.7 & 90.9 \\
Others & 1 & .2 & .2 & 91.1 \\
Total & 48 & 8.9 & 8.9 & 100.0 \\
\hline
\end{tabular}

A total of 233 respondents have their main product in the form of F \& B (43.1\%). In detail can be seen in the following table.

\begin{tabular}{|c|c|c|c|c|c|}
\hline \multicolumn{6}{|c|}{ PRODUCT } \\
\hline & & Frequency & Percent & Valid Percent & $\begin{array}{c}\text { Cumulative } \\
\text { Percent }\end{array}$ \\
\hline \multirow[t]{11}{*}{ Valid } & Furniture & 18 & 3.3 & 3.3 & 3.3 \\
\hline & Handycrafts & 8 & 1.5 & 1.5 & 4.8 \\
\hline & Garment & 63 & 11.7 & 11.7 & 16.5 \\
\hline & Household & 7 & 1.3 & 1.3 & 17.8 \\
\hline & Leather_Products & 6 & 1.1 & 1.1 & 18.9 \\
\hline & Accessories & 19 & 3.5 & 3.5 & 22.4 \\
\hline & $F \& B$ & 233 & 43.1 & 43.1 & 65.6 \\
\hline & Agriculture & 7 & 1.3 & 1.3 & 66.9 \\
\hline & Machinery_Elect_Eq & 31 & 5.7 & 5.7 & 72.6 \\
\hline & Others & 148 & 27.4 & 27.4 & 100.0 \\
\hline & Total & 540 & 100.0 & 100.0 & \\
\hline
\end{tabular}


A total of 359 respondents developed their business under the umbrella of Trade Business Law, namely $66.5 \%$. Entrepreneurs who do not pocket the business license is only known to the districts as much as 32 respondents $(5.9 \%)$. While those who develop business officially through Trading Business License is 85 respondents $(15,7 \%)$. In detail can be seen in the following table.

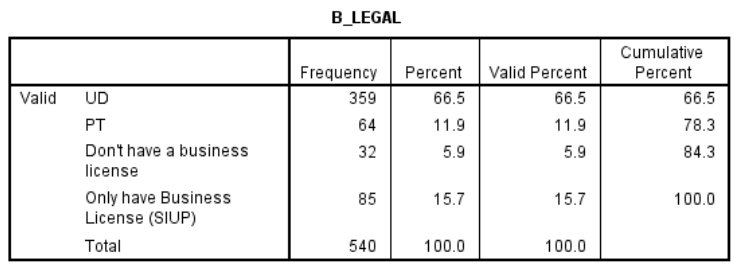

A total of 241 respondents had a turnover of $<10$ million a month. Second level as many as 103 respondents have a turnover of 10-25 million. Respondents who had the largest turnover were 10 people (3.5\%). In detail can be seen in the following table.

\begin{tabular}{|c|c|c|c|c|c|}
\hline \multicolumn{6}{|c|}{ OMZET } \\
\hline & & Frequency & Percent & Valid Percent & $\begin{array}{c}\text { Cumulative } \\
\text { Percent }\end{array}$ \\
\hline \multirow[t]{7}{*}{ Valid } & <IDR 10 Million & 241 & 44.6 & 44.6 & 44.6 \\
\hline & IDR (10-25) Million & 103 & 19.1 & 19.1 & 63.7 \\
\hline & IDR (26-100) Million & 82 & 15.2 & 15.2 & 78.9 \\
\hline & IDR (101-208) Million & 49 & 9.1 & 9.1 & 88.0 \\
\hline & IDR 209 Million-4, 1 Billion & 46 & 8.5 & 8.5 & 96.5 \\
\hline & >IDR 4,1 Billion & 19 & 3.5 & 3.5 & 100.0 \\
\hline & Total & 540 & 100.0 & 100.0 & \\
\hline
\end{tabular}

A total of 449 respondents have a strong market in the country (92\%). While those with export markets were 43 respondents (8\%). In detail can be seen in the following table.

\begin{tabular}{|c|c|c|c|c|c|}
\hline \multicolumn{6}{|c|}{ MARKET } \\
\hline & & Frequency & Percent & Valid Percent & $\begin{array}{c}\text { Cumulative } \\
\text { Percent }\end{array}$ \\
\hline \multirow[t]{3}{*}{ Valid } & Domestic & 497 & 92.0 & 92.0 & 92.0 \\
\hline & Export & 43 & 8.0 & 8.0 & 100.0 \\
\hline & Total & 540 & 100.0 & 100.0 & \\
\hline
\end{tabular}

\subsection{Test Requirements Analysis}

All data is normally distributed. And the relationship between dimensions and the main variables is also linear.

\subsection{Research Result}

1. Indonesian entrepreneurs tend to significantly virtualize at $\alpha$ $<0.05$.

2. Indonesian entrepreneurs tend to have a positive attitude significantly at $\alpha<0.05$.

3. Indonesian entrepreneurs tend to be competent significantly at $\alpha<0.05$.

4. Indonesian Entrepreneurs have an innovative-transformative effort significantly at $\alpha<0.05$.

5. Entrepreneurs Indonesia has enough capacity to realize information technology (virtual) significantly on $\alpha<0,05$.

6. There is a strong influence Has the Capacity to Realize Technology Literacy, especially Information Technology (X4) towards the Realization of Literacy Virtual Entrepreneur Indonesia (Y). It was able to determine the increase of 83,521 times from the condition of Indonesian Virtual Entrepreneur Literacy (Y).

7. Entrepreneurs Who Have Various Innovative Efforts in Achieving Business Development that Transformation (X3) will determine itself Has Capacity Realizing Technology Literacy, especially Information Technology (X4). Entrepreneur of Indonesia Who Has Various Innovative Efforts in Achieving Transformative Business Development (X3) will provide a change of 32.811 times from the condition of its capacity in realizing information technology literacy (X4).

8. Entrepreneur Indonesia Who Have Absorption Ability to Information Technology (X2_2) is very determine the occurrence of increase of 59,953 times from condition Literacy Virtual Entrepreneur Indonesia (Y). Especially if entrepreneur Indonesia Has Leadership that Transforming Business through Implementation of Information Technology (X3-4) and Literate Information Technology (X4-1). Graphically the results can be seen in the picture below.

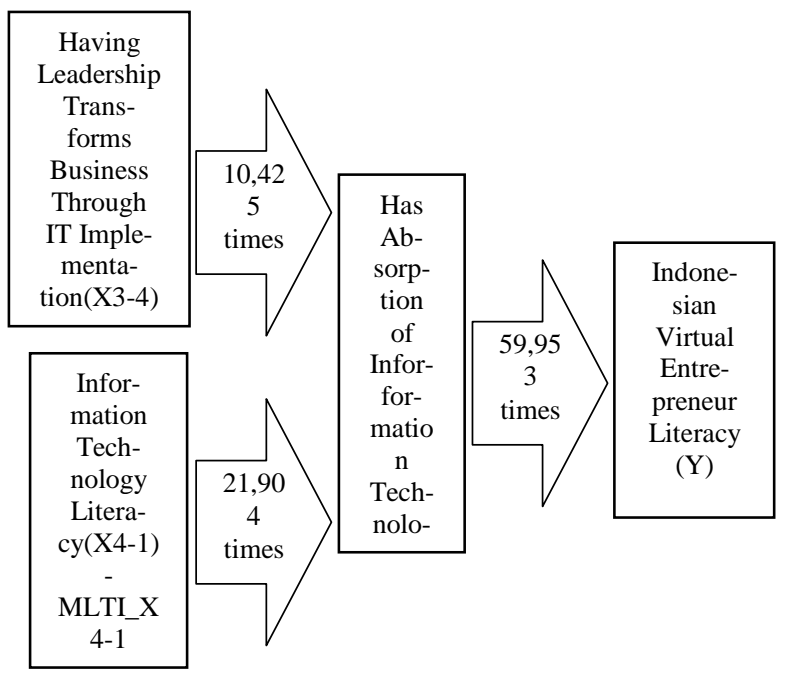

9. Indonesian Entrepreneurs Who Have the Absorption of Information Technology (X2_2) is very decisive for an increase of 59,953 times the condition of Indonesian Virtual Entrepreneurial Literacy (Y). Especially if Indonesian entrepreneurs have leadership that transforms business through the implementation of information technology (X3-4) and information technology literacy (X4-1). Graphically the results can be seen in the following figure 2 .

10. The study also found additional results that Indonesian entrepreneurs who have a strong network (Item_7) were very decisive for an increase of 53.993 times the conditions of Indonesian Virtual Entrepreneurial Literacy (Y). This can be realized, if the Indonesian entrepreneur puts forward the use of information technology in developing a business (Item_11) and is able to place human resources as business capital (Item_10). Graphically the results can be seen in the following figure.

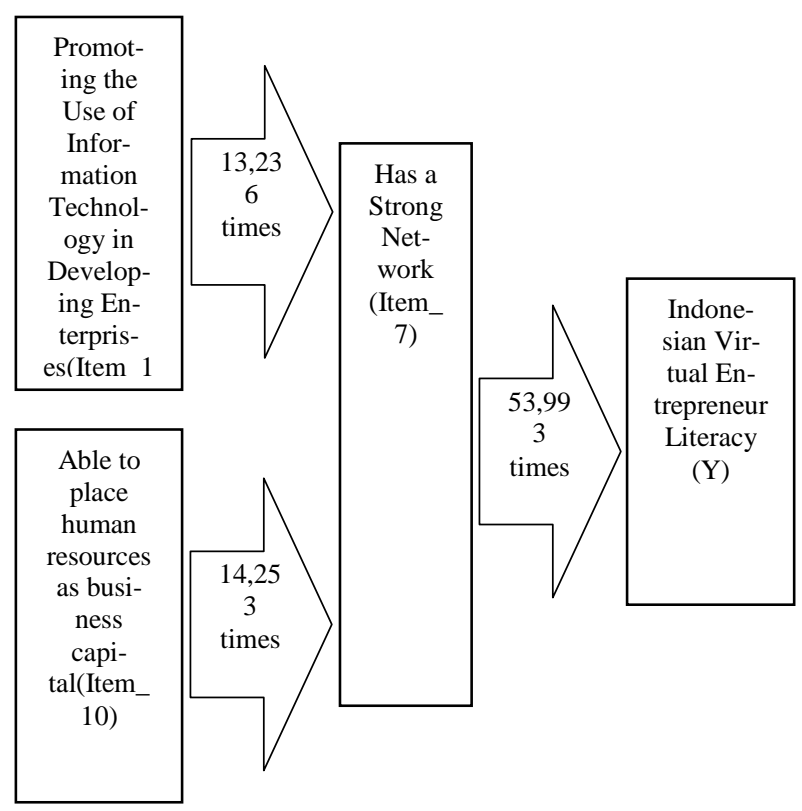


11. Entrepreneurs who must be increased capacity is from 18 districts / cities of 27 districts / cities are: West Jakarta, North Jakarta, Bitung, Manado City, Balikpapan City, Kutai Barat, Bogor, Sukabumi, Tasikmalaya, Bandar Lampung City, Mesuji, Minahasa North, Makassar City, North Toraja, Jayapura City, Asmat, Sorong, and Manokwari. Intervention of entrepreneurs in 18 districts / cities has an impact on the increase virtual literacy of 13.377 times from the current conditions. Entrepreneurial improvement in 18 districts / cities should also be considered based on the average turnover of business per month with the order of priority of the income: (1) 209 million - 4.1 billion. Then (2) $(26$ - 100) million, and so on turnover (3) < 10 million, (4) (101 - 208) million, and the last (5)> 4.1 Billion. Meaning, considering the Differences Conditions Entrepreneurs Indonesia, especially differences by District / City (X7) will determine significantly in Enhancement Literacy Virtual Entrepreneur Entire Indonesia (Y).

\section{Discussion}

The results show that although the current position of Indonesia is still not the same as some other countries but the development and progress of entrepreneurs in Indonesia is well developed. The ability of entrepreneurs in absorbing technology can be the basis for entrepreneurs to improve competitiveness so as to continue to contribute in moving the wheels of the nation's economy.

However, equity becomes very important to be followed up by the government. Differences in results from each region indicate that entrepreneurs in the region need to get more attention through various acceleration programs and increased competence so that they are able to have a competitive competitiveness in their own country.

\section{References}

[1] Cooney TM (2012), Entrepreneurship Skills for Growth-Orientated Businesses. Denish Business Authority, (November), 23.

[2] Drucker PF (1985), Innovation and Entrepreneurship. Harper \& Row $\quad 54,277$. https://doi.org/10.1023/B:BUSI.0000043501.13922.00

[3] Gorman G, Hanlon D \& King W (1997), Some research perspectives on entrepreneurship education , enterprise education and education for small business management : a ten-year literature review . International Small Business Journal 56(June).

[4] Gupta V, MacMillan IC \& Surie G (2004), Entrepreneurial leadership: Developing and measuring a cross-cultural construct. Journal of Business Venturing 19(2), 241-260. https://doi.org/10.1016/S0883-9026(03)00040-5

[5] Tambunan T (2006), Entrepreneurship Development in Indonesia. Retrieved from www. kadin-indonesia. or. id.

[6] Kementrian Koordinator Bidang Perekonomian Republik Indonesia (2017), Kewirausahaan melalui integrasi e-commerce dan media sosial.

[7] Kementrian Koperasi Republik Indonesia. Draft Rancangan Undang - Undang tentang Kewirausahaan Nasional (2018).

[8] Ács ZJ \& Szerb L (2007), The Global Entrepreneurship Index (GEINDEX). Foundations and Trends® in Entrepreneurship 5(5), 341-435. https://doi.org/10.1561/0300000027

[9] Acs ZJ, Szerb L \& Autio E (2016), Global Entrepreneurship and Development Index 2015. https://doi.org/10.1007/978-3-319-267302

[10] Boyle T (2012), 21St Century Knowledge, Skills, and Abilities and Entrepreneurial Competencies: a Model for Undergraduate Entrepreneurship Education. Journal of Entrepreneurship Education 15, 41-56. https://doi.org/10.1093/jae/ejm029 Retrieved from

http://www.oecd.org/cfe/leed/Cooney_entrepreneurship_skills_HG F.pdf

[11] Hassan Ma, Hassan MS, Shaffril HaM \& d'Silva JL (2009), Problems and obstacles in using Information and Communication Technology (ICT) among Malaysian agro-based entrepreneurs.
European Journal of Scientific Research, 36(1), 93-101. Retrieved from http://www.scopus.com/inward/record.url?eid=2-s2.070349826866\&partnerID=40\&md5=28f897baa8609ef7bcd577e574 dd55ac

[12] Ezziane Z (2007), Information technology literacy: Implications on teaching and learning. Journal of Educational Technology \& Society 10(3), 39. https://doi.org/10.1177/1473095211400151

[13] Kuratko DF (2007), Entrepreneurial Leadership in the 21 st Century. Journal of Leadership \& Organizational Studies 13(4), 1-11. https://doi.org/10.1177/10717919070130040201

[14] Isparmo (2016), Data Statistik Pengguna Internet Indonesia Tahun 2016 Pembicara Internet Marketing SEO | Konsultan.

[15] Audretsch DB, Kuratko DF \& Link AN (2015), Making sense of the elusive paradigm of entrepreneurship. Small Business Economics 45(4), 703-712. https://doi.org/10.1007/s11187-0159663-z

[16] Edward L, Kerr SP, Kerr WR, Link C, Glaeser EL, Kerr SP \& Kerr WR (2015), Entrepreneurship and Urban Growth: An Empirical Assessment with Historical Mines The Harvard community has made this article openly available. Please share how this access benefits you . Your story matters . Citation Accessed ( Article begins on next pa.

[17] Yari A, Toulabi Z \& Pourashraf Y (2013), Designing propensity to entrepreneurship paradigm in Ilam universities ( structural equation model approach ), 872-880.

[18] Sasmoko \& Anggriyani D (2016), Neuroresearch (A Model of Research Method). In A. Khan, M. N. A. Ghafar, A. R. Hamdan, \& R. Talib (Eds.), Research on Educational Studies, 33-45. New Delhi: Serial Publications PVT. LTD.

[19] Sasmoko, Indrianti Y, Karsidi R, Wuisan D \& Ruliana P (2018), Neuroresearch: Another form of mixed method. International Journal of Engineering and Technology(UAE) 7(2), 134-138. https://doi.org/10.14419/ijet.v7i2.10.10971

[20] Sasmoko, Ying Y (2015), Construct Validity in NeuroResearch. Advanced Science Letters 21(7), 2438-2441. https://doi.org/10.1166/asl.2015.6301

[21] Fios F, Sasmoko \& Gea AA (2016), Neuro-Research Method: A Synthesis Between Hermeneutics and Positivism. Advanced Science Letters 22(9), 2202-2206. https://doi.org/10.1166/as1.2016.7565 